\title{
EVALUASI PELAKSANAAN E-TENDERING PADA UNIT LAYANAN PENGADAAN DAERAH KEMENTERIAN KEUANGAN PROVINSI SULAWESI SELATAN
}

\section{EVALUATION OF E-TENDERING IMPLEMENTATION AT REGIONAL PROCUREMENT SERVICE UNIT OF MINISTRY OF FINANCE IN SOUTH SULAWESI PROVINCE}

\author{
Yohanis Salupra \\ Kementerian Keuangan RI \\ email: salupra.yohanis@gmail.com
}

\begin{abstract}
Abstrak
Pelaksanaan pengadaan barang/jasa pemerintah melalui e-tendering di Indonesia masih mengalami beberapa masalah. Seperti halnya pelaksanaan e-tendering pada Unit Layanan Pengadaan Daerah Kementerian Keuangan Provinsi Sulawesi Selatan yang mengalami tender gagal. Pada tahun 2016, jumlah tender gagal sebanyak enam paket tender gagal sebesar Rp4.695.581.000,00. Kemudian pada tahun 2017, jumlah paket tender gagal sebanyak empat paket sebesar Rp36.531.445.000,00. Pada tahun 2018, sebanyak empat paket mengalami tender gagal senilai Rp23.407.124.000,00. Sampai Agustus 2019, tender gagal terjadi sebanyak dua paket dengan nilai Rp2.061.932.000,00. Selain itu, masih terdapat adanya persekongkolan penyedia dalam mengikuti tender. Penelitian ini bertujuan untuk melakukan evaluasi terhadap Pelaksanaan E-Tendering Pada Unit Layanan Pengadaan Daerah Kementerian Keuangan Provinsi Sulawesi Selatan dengan menggunakan pendekatan deskriptif kualitatif melalui wawancara, observasi, dan studi dokumentasi. Hasil penelitian menunjukkan bahwa terdapat keterlambatan penyelesaian tender, dan penerapan reverse auction yang belum sesuai dengan ketentuan. Kecukupan biaya dan hasil dalam pelaksanaan e-tendering telah terpenuhi dan juga terjadi perataan distribusi kegiatan dan manfaat bagi setiap pihak yang terlibat secara langsung dalam proses e-tendering. Kepuasan para pihak dalam melaksanakan e-tendering adalah kemudahan akses sistem, persaingan dan prosesnya yang terbuka, dan mampu mengurangi beban kerja. Maintenance jaringan yang mengganggu jadwal tender, kewajaran nilai honorarium Pokja ULPD, dan proses pemberian penjelasan belum sesuai dengan ketentuan. Pelaksanaan e-tendering pada Unit Layanan Pengadaan Daerah Kementerian Keuangan Provinsi Sulawesi Selatan telah dilaksanakan cukup baik tetapi masih terdapat beberapa hal yang perlu dibenahi, diantaranya status ad hoc Pokja ULPD, kompetensi para pihak, koordinasi antara PPK dengan Pokja ULPD, maintenance jaringan, kewajaran nilai honorarium Pokja ULPD, dan pelaksanaan tahapan pemberian penjelasan.
\end{abstract}

Kata Kunci: Pengadaan Barang/Jasa Pemerintah, E-Tendering, Unit Layanan Pengadaan 


\begin{abstract}
The implementation of government procurement of goods / services through e-tendering in Indonesia is still experiencing several problems. As with the implementation of e-tendering at the Regional Procurement Service Unit of the Ministry of Finance of South Sulawesi Province, which experienced a failed tender. In 2016, the number of failed tenders was as many as six failed tender packages amounting to IDR 4,695,581,000.00. Then in 2017, the number of tender packages failed as many as four packages amounting to IDR 36,531,445,000.00. In 2018, four packages experienced failed tenders valued at IDR 23,407,124,000.00. Until August 2019, there were two failed tenders with a value of IDR 2,061,932,000.00. In addition, there are still suppliers' conspiracy to participate in tenders. This study aims to evaluate the implementation of E-Tendering at the Regional Procurement Service Unit of the Ministry of Finance of South Sulawesi Province using a qualitative descriptive approach through interviews, observation and documentation study. The results showed that there was a delay in the completion of the tender, and the implementation of the reverse auction was not in accordance with the provisions. Adequacy of costs and results in the implementation of e-tendering has been fulfilled and there is also an even distribution of activities and benefits for all parties directly involved in the etendering process. The satisfaction of the parties in implementing e-tendering is the ease of system access, open competition and processes, and the ability to reduce workloads. Network maintenance that interferes with the tender schedule, the fairness of the Pokja ULPD honorarium, and the process of providing an explanation are not in accordance with the provisions. The implementation of e-tendering at the Regional Procurement Service Unit of the Ministry of Finance of South Sulawesi Province has been carried out quite well but there are still several things that need to be addressed, including the ad hoc status of the ULPD Working Group, competency of the parties, coordination between PPK and Pokja ULPD, network maintenance, fairness of value. honorarium for Pokja ULPD, and implementation of the stages of giving explanations..
\end{abstract}

Keywords: Public Procurement, E-Tendering, Procurement Service Unit

\section{PENDAHULUAN}

Penerapan tata pemerintahan yang baik dan bersih (Good Governance and Clean Governance) dalam rangka pelaksanaan pembangunan nasional, perlu dilakukan dengan pengelolaan keuangan negara yang transparan, akuntabel, efisien, dan efektif. Pengelolaan keuangan negara yang efisien dan efektif dapat diimplementasikan melalui proses pengadaan barang dan jasa pemerintah. Peningkatan efisiensi dan efektivitas keuangan negara perlu didukung melalui pengadaan barang dan jasa yang tepat sasaran. Keterbatasan keuangan negara menuntut proses pengadaan yang memberikan manfaat bagi negara atas setiap anggaran yang dikeluarkan.

Di Indonesia, pengadaan barang dan jasa pemerintah telah dilaksanakan melalui e-procurement yang diterapkan oleh beberapa instansi pemerintah berdasarkan Instruksi Presiden (Inpres) Nomor 5 Tahun 2008 tentang Fokus Program Ekonomi Tahun 2008 - 2009. Kemudian pada tahun 2010 melalui Peraturan Presiden (Perpres) Nomor 54 Tahun 2010 tentang Pengadaan Barang/Jasa Pemerintah, e-procurement mulai diterapkan oleh hampir semua instansi pemerintah. Implementasi $e$ procurement dilaksanakan melalui Sistem Pengadaan Secara Elektronik (SPSE) yang 
dikembangkan oleh Lembaga Kebijakan Pengadaan Barang/Jasa Pemerintah (LKPP). SPSE terdiri atas pelaksanaan tender secara elektronik (e-tendering) dan pembelian secara elektronik (epurchasing). E-purchasing diluncurkan oleh LKPP pada tahun 2012 dengan dasar hukum Perpres Nomor 70 Tahun 2012 tentang perubahan kedua Perpres 54 tahun 2010 tentang Pengadaan Barang/Jasa Pemerintah (Sadiqa, 2017). Dengan demikian, sistem e-procurement yang digunakan dari tahun 2007 hingga tahun 2011 adalah sistem e-tendering melalui aplikasi SPSE.

Di lingkungan Kementerian Keuangan, e-procurement telah diterapkan sejak tahun 2008 melalui Layanan Pengadaan Secara Elektronik (LPSE) Kementerian Keuangan. Kemudian pada tanggal 8 April 2009 (Radit, 2017:9), Pusat Layanan Pengadaan Secara Elektronik (Pusat LPSE) Kementerian Keuangan terbentuk sebagai upaya penguatan kelembagaan di bidang pengadaan barang dan jasa pemerintah. Selanjutnya pada tahun 2013, Unit Layanan Pengadaan Daerah Kementerian Keuangan (ULPD Kemenkeu) dibentuk di setiap provinsi berdasarkan Keputusan Menteri Keuangan (KMK) No. 146/KM.1/2013 tentang Penetapan Unit Layanan Pengadaan Daerah di lingkungan Instansi Vertikal
Kementerian Keuangan. ULPD Kemenkeu ditugaskan untuk melaksanakan pengadaan barang dan jasa pemerintah melalui $e$ tendering di lingkungan Kementerian Keuangan.

Menurut beberapa penelitian, $e$ tendering telah memberikan kemajuan dalam proses pengadaan barang dan jasa pemerintah di Indonesia. Nasution (2012) menyebutkan bahwa e-procurement (etendering) dapat meningkatkan transparansi, akuntabilitas, akses pasar dan persaingan usaha yang sehat, efisiensi waktu dan biaya, mendukung proses monitoring dan audit, serta memenuhi kebutuhan akses informasi yang real time. Menurut Bawono (2011), e-tendering telah mampu meningkatkan efisiensi sebesar $12,30 \%$ yang diperoleh dari efisiensi waktu, efisiensi biaya advertisement, efisiensi biaya tender, dan efisiensi hasil pengadaan. Sedangkan menurut Aditya dan Oktaviana (2015), e-tendering membawa perubahan yaitu meminimalkan waktu, meminimalkan terjadinya kolusi, dan membuat pengadaan menjadi lebih transparan dengan indikator akses informasi yang akurat dan tepat waktu, data tersedia dan bebas diperoleh, serta aturan dan prosedur yang simple, straight forward, dan easy to apply.

Namun di sisi lain, e-tendering juga masih memiliki beberapa permasalahan. Menurut Bawono (2011), e-tendering 
memiliki kendala yaitu kurangnya kesiapan perangkat-perangkat teknologi informasi yang menunjang e-procurement, kurangnya kebijakan tentang proses bisnis $e$ procurement yang menjadi acuan pelaku pengadaan, kurangnya sosialisasi secara menyeluruh tentang e-procurement, kurangnya informasi mengenai data penyedia dalam aplikasi e-procurement, tidak terdapat rincian harga untuk pengadaan sebelumnya sebagai dasar acuan pengadaan selanjutnya, kurangnya dukungan internet, bandwith dan server yang masih belum memadai, serta permasalahan payung hukum tentang mekanisme pengadaan barang dan jasa secara keseluruhan. Menurut Udoyono (2012), terdapat beberapa penghambat dalam penerapan akuntabilitas e-tendering, yaitu minimnya monitoring tender di lapangan, penyalahgunaan wewenang, masih adanya penyimpangan kontrak, kolusi antara pejabat pelaksanan dengan rekanan, manipulasi dalam implementasi $e$ tendering, dan kelemahan Sumber Daya Manusia. Sedangkan menurut Faisol dkk. (2014), e-tendering tidak sepenuhnya mampu mencegah terjadinya kecurangan (procuremnet fraud) khususnya pada tahap perencanaan dan penyusunan dokumen tender.

Di lingkungan Kementerian Keuangan, khususnya di Unit Layanan
Pengadaan Daerah Kementerian Keuangan Provinsi Sulawesi Selatan, pelaksanaan $e$ tendering mengalami beberapa masalah, yaitu tender gagal dan persekongkolan tender. Tender gagal berarti tidak adanya peserta tender yang ditetapkan menjadi pemenang sehingga pelaksanaan pekerjaan pembangunan tidak dapat dilaksanakan. Tender gagal menyebabkan terjadinya keterlambatan dalam pelaksanaan pembangunan, seperti pembangunan jalan, pembangunan jembatan, pembangunan gedung perkantoran, penyediaan sarana dalam rangka pelaksanaan pelayanan publik, dan menghambat percepatan penyerapan anggaran sehingga berdampak pada fungsi alokasi dan fungsi distribusi APBN.

Tender gagal pada Unit Layanan Pengadaan Daerah Kementerian Keuangan Provinsi Sulawesi Selatan hampir setiap tahun terjadi di rentang tahun 2016 s.d. 2019. Pada tahun 2016, jumlah tender gagal sebanyak enam paket tender gagal sebesar Rp4.695.581.000,00 dari total 36 paket tender dengan pagu Rp40.284.336.500,00. Kemudian pada tahun 2017, jumlah paket tender gagal sebanyak empat paket sebesar Rp36.531.445.000,00 dari total 25 paket tender dengan total pagu Rp69.544.562.350,00. Tingginya nilai anggaran tender gagal pada tahun 2017 disebabkan adanya paket tender konstruksi 
pembangunan gedung kantor dengan pagu Rp34.548.065.000,00 yang mengalami tender gagal, sehingga rencana pembangunan diubah menjadi dua tahap. Pada tahun 2018, sebanyak empat paket mengalami tender gagal senilai Rp23.407.124.000,00 dari total 31 paket tender dengan total pagu Rp53.126.077.740,00. Nilai tender gagal tersebut sangat besar karena terjadinya tender gagal pada paket lanjutan pembangunan tahap II dari proses pembangunan tahap I pada tahun 2017. Sampai Agustus 2019, tender gagal terjadi sebanyak dua paket dengan nilai Rp2.061.932.000,00 dari total sepuluh paket tender yang memiliki pagu sebesar Rp10.234.418.500,00.

Menurut Karyasa et.al. (2014), tender gagal disebabkan oleh 1) tidak siap dengan pengadaan secara elektronik, 2) gagal upload dokumen penawaran, 3) kurangnya waktu yang disediakan untuk mempersiapkan dokumen penawaran, 4) terlambat mengetahui pengumuman lelang, 5) kualifikasi personil team proyek tidak sesuai, 6) tidak ada/tidak sesuai dukungan dari supplier, 7) dokumen penawaran tidak lengkap, dan 8) tidak siap dengan bukti kualifikasi yang dimiliki.

Persekongkolan/persaingan tidak sehat terjadi pada tender yang dilaksanakan pada Tahun Anggaran 2017.
Persekongkolan tersebut terbukti melalui proses penilaian Kelompok Kerja Unit Layanan Pengadaan Daerah Kementerian Keuangan Provinsi Sulawesi Selatan (Pokja ULPD) terhadap dokumen penawaran dan pengakuan dari peserta tender yang terlibat setelah dilakukan klarifikasi. Persekongkolan tersebut berupa kesamaan dokumen teknis penawaran, nilai penawaran seluruh penyedia yang terlibat mendekati Harga Perkiraan Sendiri (HPS), peserta yang terlibat berada dalam satu kendali manajemen, serta adanya kesamaan isi dan kesalahan dokumen penawaran.

Permasalahan tersebut mengindikasikan bahwa proses pengadaan belum memberikan manfaat bagi negara atas setiap anggaran yang dikeluarkan. Simatupang dan Kartika (2013) menyebutkan bahwa konsep pengadaan seharusnya memiliki konsep berkelanjutan (sustainable procurement) yang berarti bahwa pengadaan tidak hanya terbatas pada mendapatkan barang, bangunan, dan jasa, melainkan juga untuk mencapai value for money, yakni perbesaran nilai dari uang yang dikeluarkan dan memberikan manfaat nyata untuk masyarakat dan ekonomi dengan turut serta meminimalkan kerusakan lingkungan.

Konsep value for money dituangkan dalam Peraturan Presiden Nomor 16 tahun 2018 (Perpres 16) tentang Pengadaan 
Barang/Jasa Pemerintah. Pada bagian menimbang huruf (b) Perpres 16, disebutkan bahwa pengaturan pengadaan barang dan jasa pemerintah ditujukan untuk memberikan pemenuhan nilai manfaat yang sebesar-besarnya (value for money) dan kontribusi dalam peningkatan penggunaan produk dalam negeri, peningkatan peran Usaha Mikro, Usaha Kecil, dan Usaha Menengah (UMKM) serta pembangunan berkelanjutan. Konsep value for money, sesuai pasal 4 huruf (a) Perpres 16, diterjemahkan sebagai menghasilkan barang/jasa yang tepat dari setiap uang yang dibelanjakan, diukur dari aspek kualitas, jumlah, waktu, biaya, lokasi, dan penyedia.

Untuk itu, penulis melakukan evaluasi atas pelaksanaan e-tendering yang dilaksanakan pada aplikasi SPSE. Evaluasi dapat diartikan sebagai penaksiran (appraisal), pemberian angka (rating), dan penilaian (assesment) terhadap hasil kebijakan atas tujuan yang telah ditetapkan (Dunn, 2000). Menurut William Dunn (2000), pelaksanaan evaluasi memerlukan beberapa kriteria, yaitu 1) efektivitas, capaian hasil yang telah ditentukan; 2) efisiensi, usaha yang diperlukan untuk mencapai hasil; 3) kecukupan, tingkat masalah yang terselesaikan dari hasil kebijakan; 4) perataan, pendistribusian biaya dan manfaat secara merata kepada kelompok yang berbeda; 5) responsivitas, kepuasan kelompok sasaran terhadap hasil kebijakan dan 6) ketepatan, hasil yang diinginkan memiliki nilai manfaat.

Atas dasar hal-hal yang telah diuraikan, maka tujuan penelitian ini adalah untuk mengevaluasi pelaksanaan $e$ tendering pada Unit Layanan Pengadaan Daerah Kementerian Keuangan Provinsi Sulawesi Selatan dalam rangka mewujudkan tujuan pengadaan barang dan jasa pemerintah sesuai dengan konsep value for money.

\section{METODE PENELITIAN}

Metode penelitian yang digunakan pada penelitian ini adalah metode kualitatif dengan pendekatan deskriptif. Penelitian ini dilakukan di Unit Layanan Pengadaan Daerah Kementerian Keuangan Provinsi Sulawesi Selatan pada bulan FebruariMaret 2020. Pengumpulan data dilakukan dengan wawancara mendalam, observasi, dan dokumentasi. Informan penelitian ini adalah Ketua Pokja ULPD, Sekretaris Pokja ULPD, Pejabat Pembuat Komitmen (PPK), Penyedia, dan Administrator SPSE. Selain itu, dokumen pengadaan, laporan ULPD, catatan-catanan dan dokumendokumen terkait juga menjadi bagian dari data dalam penelitian ini. Teknik analisis data yang digunakan adalah model analisis interaktif. Model analisis interaktif ini 
terdiri atas tiga komponen analisis (Miles dan Huberman, 1992), yaitu reduksi data, penyajian data, dan penarikan kesimpulan. Komponen-komponen tersebut memiliki keterkaitan hingga tahap akhir proses analisis data. Keabsahan data yang digunakan pada penelitian ini adalah dengan menggunakan teknik triangulasi.

\section{HASIL PENELITIAN}

Dalam melaksanakan evaluasi etendering ini, penulis melakukan wawancara terhadap Ketua dan Sekretaris Pokja ULPD. ULPD yang dibentuk di setiap provinsi berdasarkan Keputusan Menteri Keuangan (KMK) Nomor 146/KM.1/2013 tentang Penetapan Unit Layanan Pengadaan Daerah Di Lingkungan Instansi Vertikal Kementerian Keuangan memiliki personil atau anggota yang bersifat ad hoc. Dengan demikian, pelaksanaan e-tendering merupakan tugas dan tanggung jawab diluar pekerjaan pokok anggota Pokja ULPD. Selain Ketua dan Sekretaris Pokja ULPD, penulis juga melakukan wawancara terhadap Pejabat Pembuat Komitment (PPK) di salah satu satuan kerja di lingkungan Kementerian Keuangan, Administrator LPSE sebagai pengelola sistem pengadaan di lingkungan Kementerian Keuangan Provinsi Sulawesi Selatan, dan salah satu Penyedia yang sering mengikuti tender di lingkungan
Kementerian Keuangan Provinsi Sulawesi Selatan.

Pokja ULPD memiliki tugas untuk melaksanakan tender melalui SPSE yang menetapkan pemenang tender untuk diserahkan kepada PPK. PPK bertugas menyusun dokumen perencanaan pengadaan terkait barang/jasa yang dibutuhkan oleh satuan kerja yang bersangkutan. Administrator LPSE bertugas sebagai penyedia layanan SPSE untuk melaksanakan proses tender. Penyedia merupakan pelaku usaha yang mengikuti tender dan kemudian akan ditetapkan sebagai pelaksana pekerjaan pengadaan barang/jasa pemerintah.

Adapun proses e-tendering berdasarkan Peraturan LKPP Nomor 9 Tahun 2018 tentang Pedoman Pelaksanaan Pengadaan Barang/Jasa Melalui Penyedia yaitu 1) PPK menyampaikan dokumen persiapan pengadaan kepada Kepala Unit Layanan Pengadaan Daerah melalui aplikasi sistem pengadaan secara elektronik (SPSE) yang dapat diakses melalui www.lpse.kemenkeu.go.id. 2) Kemudian Kepala ULPD menetapkan Pokja ULPD untuk melakukan kaji ulang dokumen persiapan pengadaan, menetapkan metode pemilihan Penyedia, menetapkan metode kualifikasi, menetapkan persyaratan penyedia, menetapkan metode evaluasi penawaran dan metode penyampaian 
dokumen penawaran, menyusun dan menetapkan jadwal pemilihan, serta menyusun dokumen pemilihan. 3) Pokja ULPD mengumumkan paket tender di website melalui SPSE. 4) peserta tender (penyedia) mengikuti dan mengunduh Dokumen Pemilihan. 5) Tahapan pemberian penjelasan (Aanwijzing) yaitu forum tanya jawab antara Peserta Tender dengan Pokja ULPD mengenai ruang lingkup pengadaan serta syarat dan ketentuan yang tercantum dalam Dokumen Pemilihan sehingga terdapat kesamaan pemahaman antara Pokja Pemilihan dan Peserta, sekaligus untuk mendapatkan masukan kemungkinan adanya koreksi atas Dokumen Pemilihan. 6) Tahap selanjutnya adalah tahap pemasukan dokumen penawaran oleh peserta tender, pembukaan dokumen penawaran oleh Pokja ULPD, evaluasi/penilaian administrasi, teknis, harga dan kualifikasi peserta tender oleh Pokja ULPD untuk menentukan kelulusan peserta tender. Pada proses tersebut terdapat tahapan pembuktian kualifikasi, yang membuktikan kebenaran dokumen kualifikasi peserta tender.

7) Kemudian tahap penetapan pemenang tender. 8) Tahapan terakhir dari proses tender adalah tahap sanggah sebagai media bagi peserta tender yang merasa dirugikan atas hasil e-tendering.
Evaluasi menghasilkan informasi mengenai kinerja kebijakan. Untuk mendapatkan informasi mengenai kinerja kebijakan, maka dibutuhkan kriteriakriteria evaluasi. Menurut William Dunn (2000:610), kriteria evaluasi terdiri atas efektifitas, efisiensi, kecukupan, perataan, responsivitas, dan ketepatan.

Kriteria efektivitas menekankan kepada hasil atau pencapaian tujuan pelaksanaan e-tendering dalam hal pencapain value for money. Tujuan pelaksanaan e-tendering belum tercapai sepenuhnya, karena masih mengalami keterlambatan waktu seperti adanya pengluangan proses tender, penerapan reverse auction yang belum sesuai ketentuan, dan jadwal maintenance jaringan yang mempengaruhi tahapan tender. Ketua Pokja ULPD mengatakan bahwa masih adanya celah dan kelemahan di sana. Diantaranya menyempitkan kesempatan untuk rekanan-rekanan lokal dan masalah maintenance jaringan. Rekanan dari luar menang itu konsekuensi pengadaan eletronik. Jadi terbuka untuk umum karena tujuannya untuk bersaing dengan semuanya yang mampu termasuk di luar daerah. Tapi sedikit juga yang menang dari luar daerah. Penyedia barang/jasa menyampaikan bahwa:

"Sebenarnya kalau di Kementerian Keuangan itu sudah memenuhi. Tapi, ada yang namanya reverse auction, di 
situlah harga semua jatuh. Sekarang meskipun urutan kami urutan pertama, kalau masuk reverse auction, kita menawar ulang lagi, pasti kualitasnya turun" (RA, Maret 2020).

Dari hasil penelusuran dokumen, penulis menemukan tiga paket tender jasa lainnya yang dilakukan reverse auction, yaitu berupa paket tender pengadaan jasa pengolahan data dan dokumen, pengadaan jasa pemeliharaan halaman gedung, dan pengadaan jasa satuan pengamanan kantor. Selain itu, penulis menemukan beberapa paket tender yang mengalami pengulangan proses, berupa tender ulang, evaluasi ulang, dan pemasukan penawaran ulang. Dari total 36 paket tender selama awal tahun 2019 hingga awal tahun 2020, terdapat tiga paket tender yang mengalami tender ulang, dua paket tender yang mengalami evaluasi ulang, dan satu paket tender yang mengalami pemasukan penawaran ulang. Paket tender tersebut adalah pengadaan jasa mekanikal elektrikal, pengadaan barang Air Conditioner (AC), renovasi rumah dinas eselon III, pengadaan jasa konsumsi peserta pelatihan, pengadaan seragam dan perlengkapan peserta pelatihan teknis kesamaptaan, serta pengadaan jasa penyediaan pengharum ruangan dan alat sanitasi.

Kriteria evaluasi yang kedua adalah efisiensi, yaitu jumlah usaha yang diperlukan untuk mendapatkan tingkat capaian tertentu. Dalam pelaksanaan $e$ tendering, terdapat efisiensi biaya dan kegiatan. Efisiensi biaya terdiri atas biaya alat tulis kantor, biaya perjalanan, dan biaya rapat. Efisiensi kegiatan terdiri atas efisiensi waktu dan tempat. Selain itu, juga terdapat penghematan nilai dari outcome kontrak, yang diperoleh dari perbandingan antara nilai HPS dengan nilai kontrak. Ketua Pokja ULPD mengatakan bahwa:

"Dengan adanya sistem digital, semua pihak tanpa terkecuali tanpa harus terbatasi oleh kondisi geografi atau akses transportasi, bisa dari mana saja memiliki kesempatan yang sama. Biaya yang timbul, pertama adalah kita menggunakan alat tulis kantor, kemudian pembuktian lapangan, dan biaya akomodasinya evaluasi" (AWM, Februari 2020).

$$
\text { Penyedia barang/jasa juga }
$$

menyampaikan bahwa:

"Biasanya yang kami keluarkan itu cuma materai, kertas juga tidak seberapa. Paling yang kami keluarkan sekitar tiga ratus ribu. Jadi sekarang biayanya minim"'(RA, Maret 2020).

Informan lainnya juga

menambahkan:

"Penghematan itu ya penggunaan kertas, pertemuan jadi kurang, waktu jadi lebih singkat. Terus penghematan nilai kontrak. Selama lewat elektronik, ada penghematan signifikan dari HPSnya PPK” (ES, Maret 2020).

Dari hasil pengamatan penulis, biaya-biaya yang dikeluarkan oleh penyedia sebagai peserta tender adalah 
biaya internet untuk mengakses SPSE (kecuali menggunakan wifi), biaya percetakan dokumen penawaran untuk kelengkapan pembuktian kualifikasi, dan biaya perjalanan ke kantor ULPD saat pembuktian kualifikasi (kecuali pembuktian lapangan dilakukan di kantor penyedia).

Kriteria kecukupan menekankan kecukupan biaya dan kecukupan hasil. Biaya yang telah disiapkan dalam proses $e^{-}$ tendering telah mencukupi. Proses tender yang dilakukan secara elektronik telah mampu mengurangi biaya-biaya yang timbul dari pelaksanaan tender. Proses $e$ tendering telah menghasilkan penyediapenyedia yang secara kualifikasi telah sesuai dengan bidang pekerjaan yang ditenderkan karena telah memenuhi persyaratan kualifikasi, administrasi, teknis, dan harga penawaran. Hasil wawancara dengan Ketua Pokja ULPD adalah sebagai berikut:

"Selama ini biaya-biaya tersebut disiapkan oleh PPK. Unsur dari biayabiaya itu kan ada biaya proyek, ada biaya orang per jam, dan seterusnya. Terkait dengan hasil tender, PPK yang menilai. Kalau ULP menilai administrasi, secara dokumen" (AWM, Februari 2020).

Informan lain juga menambahkan, bahwa:

"Ya, proses digitalisasi itu. Seperti yang saya bilang, itu supaya mudah dan biayanya minimal. Makanya digitalisasi, dan ULP hanya lihat sesuai persyaratannya, sesuai administrasinya saja” (ES, Maret 2020).

Dari sisi hasil, PPK menyatakan bahwa Penyedia Barang/Jasa selama ini sudah sangat baik, telah sesuai dengan harapan dan juga PPK mengontrol barang/jasa yang diadakan oleh Penyedia melalui tanda terima atau checklist. PPK juga menambahkan bahwa dengan adanya e-tendering mengurangi PPK untuk bertatap muka dengan Penyedia, dan juga $e$ tendering membuat siapa saja bisa mengikuti proses tender (AF, Maret 2020).

Kriteria perataan berkaitan dengan distribusi kegiatan dan distribusi manfaat. Distribusi kegiatan dalam proses $e$ tendering telah berjalan sesuai dengan ketentuan. Setiap pihak dalam proses $e$ tendering mendapatkan manfaat yang sama, yaitu berupa kemudahan dalam melaksanakan proses e-tendering. PPK di salah satu satuan kerja Kementerian Keuangan mengatakan bahwa:

"Kita kan ada area-areanya ya, tupoksinya ULP apa, PPK juga. Kita masing-masing saja areanya" (AF, Maret 2020).

Informan lain juga menambahkan, bahwa:

"Di sistem sudah dibagi-bagi kewenangan-nya, di awal ada PPK kirim paket tender, terus sama ULPD diteruskan ke Pokja, nah Pokja sesuai aturan dari awal sampai akhir tender, di 
tengah proses ada penyedia. (ES, Maret 2020).

Terkait dengan distribusi manfaat, Ketua Pokja ULPD menyatakan bahwa manfaat proses e-tendering adalah efisiensi, meminimalkan pertemuan dengan calon penyedia, dan kurangnya intervensi dari pihak tertentu (AWM, Februari 2020). Hal tersebut senada dengan pendapat Penyedia yang menyatakan bahwa semua penyedia dapat mengikuti tender di lingkungan Kementerian Keuangan dan juga tidak merasakan adanya tindakan diskriminatif dari anggota Pokja ULPD (RA, Maret 2020).

Kriteria responsvitas berkaitan dengan seberapa jauh suatu kebijakan dapat memuaskan kebutuhan, preferensi, dan nilai dari kelompok-kelompok masyarakat tertentu atau berhubungan dengan tingkat kepuasan atas manfaat yang diperoleh. Kepuasan para pihak yang terlibat adalah terpenuhinya kebutuhan dalam proses $e$ tendering berupa kemudahan akses sistem e-tendering yang dapat dilakukan kapan pun dan di mana pun, keterbukaan persaingan dan proses tender, serta mengurangi beban kerja dalam proses tender. Ketua Pokja ULPD menyatakan bahwa:

"Kan kita ingin mendapatkan hasil pekerjaan yang bisa memenuhi kebutuhan instansi, kebutuhan satker pemerintah. Selama ini kami melihat sudah terpenuhi disitu” (AWM, Februari 2020).

Dari hasil pengamatan penulis, pengadaan melalui e-tendering dapat mengurangi beban kerja Pokja ULPD, PPK dan Penyedia. Melalui sistem ini, Pokja ULPD dapat melakukan evaluasi dokumen penawaran secara otomatis, secara khusus pada saat evaluasi harga dan koreksi aritmatik. Sistem akan mendeteksi secara otomatis harga yang melampaui HPS dan mengkoreksi harga sesuai dengan yang diinput oleh peserta tender. Melalui $e$ tendering, PPK dapat melihat perkembangan proses tender. Bagi penyedia, e-tendering membuat proses tender menjadi transparan karena penyedia dapat mengetahui proses evaluasi administrasi, teknis, harga, dan kualifikasi sehingga dapat meminimalkan kecurangan dalam proses tender.

Namun, ada beberapa hal yang menjadi kekurangan dan kelemahan dalam proses pelaksanaan e-tendering, yaitu maintenance jaringan yang mengganggu jadwal e-tendering, sistem reverse auction yang belum sepenuhnya dipahami oleh setiap pihak, kewajaran nilai honorarium Pokja ULPD, dan proses pemberian penjelasan yang belum berjalan sebagaimana mestinya. Sebagian seperti yang diungkapkan oleh Ketua Pokja ULPD: 
"Honorarium jelas tidak wajar. Saya berharap ada perhitungan yang lebih detail, dibuat suatu formulanya. Kendala yang utama dalam pelaksanaan e-tendering ini adalah masalah maintenance jaringan yang menghambat pelaksanaan e-tendering yang sudah terjadwal sampai akhir" (AWM, Februari 2020).

Selanjutnya informan dari penyedia menambahkan bahwa

"Kalau prosesnya sudah puas. Kecuali reverse auction dan proses aanwijzing. Biasanya kami bertanya tidak langsung dijawab sama panitia, dijawab sama panitia sudah tutup, dan mau bertanya balik sudah tidak bisa" (RA, Maret 2020).

Dari hasil penelusuran penulis, reverse auction dilaksanakan terhadap beberapa paket tender jasa lainnya.

Kriteria ketepatan mempertanyakan apakah tujuan kebijakan tersebut tepat untuk suatu masyarakat. Nilai dari tujuan kebijakan e-tendering secara khusus untuk pencapaian valur for money sudah tepat. Tujuan berdasarkan nilai-nilai dari value for money berupa aspek kualitas, jumlah, waktu, biaya, lokasi, dan penyedia telah sesuai karena telah memberikan perhatian atas besaran nilai uang yang dikeluarkan dan memberikan manfaat nyata untuk masyarakat dan ekonomi. PPK menyatakan bahwa:

"Pasti perubahan ketentuan itu ada beberapa pertimbangan, di lapangan seperti apa makanya ada perubahan.
Intinya itu sudah memenuhi value for money" (AF, Maret 2020).

Informan lain juga menyampaikan bahwa:

"Tujuannya itu sudah sangat tepat. Tinggal bagaimana diimplementasikan supaya terwujud" (ES, Maret 2020).

\section{PEMBAHASAN}

Berdasarkan hasil penelitian, penulis menemukan beberapa temuan terkait dengan pelaksanaan e-tendering di lapangan. Beberapa temuan dimaksud adalah Anggota Kelompok Kerja Unit Layanan Pengadaan Daerah Kementerian Keuangan (Pokja ULPD) bersifat ad hoc, terjadi pengulangan proses tender, penerapan reverse auction pada semua jenis tender, maintenance jaringan yang mempengaruhi jadwal e-tendering, kewajaran nilai honorarium Pokja ULPD, serta proses pemberian penjelasan yang belum berjalan sebagaimana mestinya.

1) Pokja ULPD Bersifat Ad Hoc Anggota Pokja ULPD di lingkungan Kementerian Keuangan Provinsi Sulawesi Selatan terdiri atas pegawai yang diperbantukan dari satuan kerja lain di lingkungan Kementerian Keuangan. Artinya bahwa pegawai dimaksud memiliki tugas pokok lain yang menjadi rutinitas sehingga tidak fokus melaksanakan tender di lingkungan Kementerian Keuangan Provinsi Sulawesi 
Selatan. Untuk melayani tender di lingkungan Kementerian Keuangan Provinsi Sulawesi Selatan, Anggota Pokja ULPD harus membagi waktu agar pelaksanaan tugas pokoknya tidak terganggu yang di sisi lain juga melaksanakan proses e-tendering. Hal ini menyebabkan Anggota Pokja ULPD mengerjakan proses $e$-tendering di luar jam kerja, kecuali mendapatkan surat tugas di jam kerja untuk mengerjakan tender.

Situasi seperti ini akan mengganggu konsentrasi Pokja ULPD dalam melaksanakan pekerjaan, secara khusus dalam melaksanakan tender. Pelaksanaan tender yang memiliki konsekuensi hukum berkaitan dengan pihak ketiga dalam proses penentuan pemenang tender, maka tidak dapat dijadikan pekerjaan tambahan di luar pekerjaan pokok. Anggota Pokja ULPD yang bersifat ad hoc dapat mengakibatkan kesalahan penilaian penyedia pada proses tender sehingga mengakibatkan tender gagal, tahapan pemberian penjelasan yang tidak maksimal, dan kurangnya pelaksanaan bimbingan terhadap peserta tender. Pelaksanaan bimbingan teknis atau sosialisasi terkait dengan pelaksanaan tender dilakukan agar tidak lagi terdapat penyedia yang surat penawarannya tidak lengkap sehingga gugur ditahap evaluasi administrasi, teknis, harga, dan kualifikasi.

\section{2) Pengulangan Proses Tender}

Pengulangan proses tersebut yaitu tender ulang, evaluasi ulang, dan pemasukan penawaran ulang. Penyebabnya adalah a) seluruh penyedia yang memasukan penawaran tidak memenuhi syarat sehingga terjadi tender gagal, b) tidak adanya penyedia yang memasukan penawaran pada tender cepat, c) adanya sanggahan penyedia yang dinyatakan benar, dan d) tidak ada penyedia yang memasukan penawaran.

Tidak adanya penyedia yang memenuhi syarat berarti surat penawaran penyedia tidak lengkap, seperti tidak melampirkan ijin perusahaan dan metode pelaksanaan pekerjaannya, jadwal pelaksanaan tidak sesuai persyaratan, dan bukti kepemilikan peralatan tidak sesuai. Hal ini menandakan bahwa penyedia kurang teliti atas surat penawaran yang disampaikan sebab sudah jelas persyaratan yang harus dilengkapi.

Tidak terdapat penyedia yang memasukan penawaran pada tender cepat dapat dimaklumi oleh karena tender cepat merupakan metode tender yang baru di kalangan penyedia saat ini. Hal ini berarti tender cepat belum dipahami sebagaimana mestinya oleh penyedia.

Sanggahan penyedia yang dinyatakan benar dapat terjadi oleh karena kekeliruan Pokja ULPD dalam melakukan evaluasi dokumen penawaran penyedia. 
Menurut penulis, hal ini dapat terjadi oleh karena status Anggota Pokja ULPD yang sifatnya ad hoc. Situasi ad hoc pada Anggota Pokja dapat menyebabkan permasalahan-permasalahan dalam pelaksanaan tender. Selain itu, peningkatan kompetensi melalui penyegaran pemahaman proses tender perlu diberikan untuk meningkatkan kompetensi dan pengetahuan Anggota Pokja ULPD.

Tidak adanya penyedia yang memasukan penawaran membuat tender tersebut harus diulang pada tahapan pemasukan penawaran. Untuk menghindari hal tersebut menurut penulis, pada tahap persiapan tender baik dari sisi Pokja ULPD maupun dari sisi PPK perlu melakukan penelusuran terkait dengan penyediapenyedia yang bergerak pada tender tersebut. Jika ternyata penyedia yang ada sedikit dapat dilakukan sounding atau pemberitahuan bahwa akan ada tender yang berhubungan dengan bidang pekerjaannya, tanpa memberikan janji tertentu kepada penyedia tersebut. Jika ternyata penyedia yang ada tidak memiliki pengalaman mengikuti tender, maka perlu diberikan informasi terkait dengan tata cara tender yang saat ini telah tersedia di banyak media daring atau dapat diberikan bimbingan secara langsung.

Pengulangan proses tersebut menyebabkan terjadinya keterlambatan dalam proses tender sehingga penerimaan barang/jasa oleh PPK juga mengalami penundaan. Secara umum, mengulang proses tender menyebabkan terjadinya keterlambatan dalam pelaksanaan pembangunan, penyediaan sarana dalam rangka pelaksanaan pelayanan publik, dan menghambat percepatan penyerapan anggaran sehingga berdampak pada fungsi alokasi serta fungsi distribusi APBN.

\section{3) Penerapan Reverse Auction}

Penerapan reverse auction dalam proses e-tendering merupakan hal yang baru sehingga dalam penerapannya masih memiliki kendala, salah satunya terkait dengan pemahaman reverse auction. Pemberlakuan reverse auction pada paket pekerjaan jasa lainnya menurut penulis akan mempengaruhi kualitas layanan dari penyedia jasa. Dalam praktek tender pengadaan jasa outsourcing, penyedia jasa akan mendapakan management fee sebagai imbalan dalam menyediakan, mengatur, dan bertanggung jawab atas tenaga kerja yang diberikan. Jika dilakukan reverse auction, maka akan terjadi persaingan harga dengan menurunkan harga penawaran. Penurunan harga tersebut dapat menyebabkan kualitas layanan penyedia jasa outsourcing menjadi rendah.

Penurunan harga tersebut dapat mengakibatkan pemangkasan gaji tenaga kerja untuk mengembalikan pendapatan 
yang hilang oleh karena proses reverse auction. Penyedia jasa juga dapat mengurangi uang lembur tenaga kerja jika ada pekerjaan lembur. Hal ini dapat terjadi karena tenaga outsourcing berada dibawah pengaturan dan tanggung jawab penyedia jasa tenaga kerja. PPK sebagai pengguna tenaga kerja berhubungan secara langsung dengan penyedia tenaga kerja melalui kontrak/surat perjanjian sehingga penyedia jasa tenaga kerja sangat mungkin mengurangi kualitas layanan melalui pemotongan pendapatan tenaga kerja yang disediakan bagi PPK. Dengan demikian, reverse auction seharusnya dilakukan terhadap pekerjaan sesuai dengan kriteria yang telah disebutkan dalam Peraturan LKPP Nomor 9 Tahun 2018.

Kriteria reverse auction berdasarkan Peraturan LKPP Nomor 9 Tahun 2018 adalah a) Barang/Jasa rutin, volume besar, dan resikonya rendah; $b$ ) Barang/Jasa yang memiliki spesifikasi sederhana dan tidak ada perbedaan spesifikasi antar Pelaku Usaha; c) Tidak ada tambahan layanan atau pekerjaan lain yang spesifik, misalnya tidak ada penambahan pekerjaan instalasi; dan/atau d) Pada pasar persaingan kompetitif dengan jumlah sekurangkurangnya dua peserta yang mampu dan bersedia berpartisipasi pada Ereverse Auction. Contoh produk atau komoditas yang bisa diadakan melalui $E$ reverse Auction menurut Peraturan LKPP Nomor 9 Tahun 2018 adalah a) bahan bangunan seperti baja, besi, beton, pipa tembaga; b) peralatan teknologi informasi standar seperti komputer desktop, perangkat lunak standar, modem, toner catridge; c) alat tulis kantor; d) bahan kimia dan beberapa produk farmasi umum; atau e) pakaian dan seragam dengan ukuran, warna, dan volume yang standar.

Menurut penulis, paket pekerjaan jasa lainnya tersebut memiliki tambahan layanan pekerjaan lain. Misalnya untuk paket pekerjaan jasa kebersihan, terdapat layanan tambahan lain seperti menyiapkan dan membereskan perlengkapan kegiatan sosialisasi atau kegiatan lainnya melewati jam kerja, membantu pelaksanaan kegiatan pada hari-hari tertentu seperti hari perayaan ulang tahun institusi, dan pekerjaanpekerjaan tambahan lainnya diluar jam kerja/lembur atau bahkan pada hari libur.

Selain itu, pada saat melaksanakan proses reverse auction, identitas penyedia yang tidak lagi menjadi rahasia. Penyedia dapat saling mengenali pada saat proses pembuktian kualifikasi yang dilakukan di Kantor Pokja ULPD. Hal ini tentunya tidak sesuai dengan ketentuan mengenai reverse auction bahwa identitas penyedia bersifat 
rahasia selama proses reverse auction berlangsung.

\section{4) Maintenance Jaringan E-Tendering}

Pelaksanaan $e$-tendering terdiri atas beberapa tahapan dengan jadwal yang telah ditentukan oleh Pokja ULPD. Dalam pelaksanaannya, jadwal e-tendering terkadang mengalami perubahan yang disebabkan salah satunya oleh maintenance jaringan. Waktu yang dibutuhkan dalam proses maintenance jaringan aplikasi SPSE adalah satu hari atau bahkan lebih tergantung pada tingkat kesulitan dalam perbaikan sistem. Pada saat maintenance SPSE berlangsung, e-tendering tidak dapat diakses oleh semua pihak. Jika berlangsungnya maintenance bersamaan dengan jadwal pada tahapan tertentu seperti hari terakhir upload dokumen penawaran, maka jadwal tersebut harus diubah oleh Pokja ULPD pada sistem e-tendering agar lamanya setiap tahapan tersebut sesuai dengan ketentuan. Hal ini akan memperlambat proses e-tendering secara keseluruhan. Jadwal yang diatur oleh Pokja ULPD telah disesuaikan pada jadwal penandatanganan kontrak sesuai dengan perencanaan PPK. Jika salah satu jadwal tertunda maka akan mempengaruhi jadwal selanjutnya.

Pada saat maintenance akan dilaksanakan, Pokja ULPD dan setiap pihak dalam proses e-tendering tidak mendapatkan informasi sebelum pelaksanaan maintenance tersebut, kecuali pemberitahuan yang tertera pada aplikasi SPSE ketika proses maintenance sedang berlangsung. Jika informasi maintenance telah disampaikan sebelumnya, Pokja ULPD dapat memberitahukan kepada PPK terkait dengan proses maintenance tersebut sehingga membuat perencanaan kembali untuk pelaksanaan kontrak. Jika pelaksanaan maintenance dilaksanakan pada saat proses e-tendering berlangsung, maka Pokja ULPD dapat melakukan perubahan jadwal sebelumnya sehingga dapat diketahui oleh setiap peserta tender.

Menurut penulis, maintenance jaringan adalah sesuatu yang harus dilakukan untuk memberikan kelancaran dan kenyamanan dalam menggunakan sistem. Untuk itu, pelaksanaan maintenance jaringan dilakukan di luar jam kerja atau di luar hari kerja seperti hari sabtu atau minggu sehingga tidak mengganggu proses pelaksanaan tender. Selain itu, sejak awal PPK di lingkungan Kementerian Keuangan Provinsi Sulawesi Selatan seharusnya menyiapkan dan menyampaikan dokumen rencana pelaksanaan tender kepada Pokja ULPD sehingga pelaksanaan tender tidak terlalu berdekatan dengan pelaksanaan pekerjaan. PPK sudah harus memperhitungkan hal-hal yang dapat memperlambat penyelesaian 
tender, seperti tender gagal, evaluasi ulang, pemasukan penawaran ulang, dan permasalahan jaringan.

\section{5) Kewajaran Nilai Honorarium}

Dalam melaksanakan proses pemilihan penyedia barang/jasa pemerintah melalui e-tendering, terdapat resiko hukum yang dihadapi oleh Pokja ULPD. Menurut Mustafa (2010), hal yang sering dihadapi oleh Anggota Pokja ULPD adalah adanya tekanan dari penyedia barang/jasa, pemeriksaan intensif dari Inspektorat, BPKP, BPK, dan KPK, serta tekanan dari pihak pemegang kekuasaan yang hendak bermain-main. Transparansi yang terjadi akibat penerapan e-tendering melalui SPSE menyebabkan Pokja ULPD harus semakin cermat, teliti, dan patuh terhadap ketentuan pengadaan barang/jasa pemerintah (Anonim, 2017). Jika terjadi kekeliruan dan kesalahan yang tidak sesuai ketentuan, oleh karena proses yang transparan, maka Pokja ULPD menyiapkan diri untuk menghadapi gugatan peserta tender atas setiap keputusan yang diambil oleh Pokja ULPD.

Pokja ULPD memiliki resiko hukum atas setiap keputusan yang diambil. Tuntutan hukum dapat terjadi jika terdapat penyedia yang tidak puas atas hasil evaluasi dan proses sanggah, sehingga Pokja ULPD akan menghadapi proses hukum yang sangat panjang. Resiko hukum tetap melekat pada Anggota Pokja ULPD yang telah melaksanakan tender sampai pada masa kedaluwarsa hukum sehingga tidak dapat dituntut lagi. Salah satu bagian pada Pasal 78 ayat (1) Kitab Undang-Undang Hukum Pidana (KUHP) menyatakan bahwa daluwarsa hukum mengenai kejahatan yang diancam dengan pidana denda, pidana kurungan, atau pidana penjara paling lama tiga tahun, terjadi sesudah enam tahun. Jadi, Anggota Pokja ULPD menunggu sampai lebih dari enam tahun sejak terungkapnya indikasi melawan hukum dalam proses tender untuk merasa bebas dari resiko hukum. Itu merupakan salah satu contoh untuk ancaman pidana paling lama tiga tahun. Jika ancaman pidana lebih dari tiga tahun, maka kedaluwarsa hukum terjadi setelah dua belas tahun. Ancaman pidana lebih dari tiga tahun kemungkinan dapat terjadi pada paket tender dengan nilai HPS di atas Rp500 miliar dengan honorarium Anggota Pokja ULPD sebesar Rp3.200.000,00. Hal ini sangat tidak sebanding dengan jumlah honorarium yang diterima oleh Anggota Pokja ULPD. Resiko hukum akan menjadi lebih mudah didapatkan ketika status pegawai sebagai Anggota Pokja ULPD bersifat ad hoc.

Perlu diketahui juga bahwa proses pelaksanaan tender untuk satu paket pekerjaan memerlukan waktu yang cukup lama, yaitu paling cepat 15 hari untuk metode tender pascakualifikasi satu file, 
belum termasuk sanggah banding untuk pengadaan konstruksi. Lamanya waktu sanggah banding untuk pengadaan konstruksi adalah lima hari kerja setelah jawaban sanggah dan jawaban sanggah banding paling lambat 14 hari kerja setelah menerima klarifikasi jaminan sanggah banding. Untuk waktu yang lama dan resiko yang besar dalam proses tender, Pokja ULPD mendapatkan honorarium dengan nilai seperti yang tertera pada Peraturan Menteri Keuangan (PMK) Nomor 78/PMK.02/2019 tentang Standar Biaya Masukan Tahun 2020. Misalnya untuk tender konstruksi dengan pagu Rp1 miliar s.d. Rp2,5 miliar, honorarium Pokja ULPD sebesar Rp1.270.000,00 atau pagu tender konstruksi Rp750 miliar s.d. Rp1 triliun, honorarium Pokja ULPD sebesar Rp4.940.000,00.

Salah satu syarat untuk menjadi Anggota Pokja ULPD adalah memiliki sertifikat keahlian pengadaan barang/jasa sehingga pekerjaan ini merupakan pekerjaan keahlian. Tidak semua pegawai di lingkungan Kementerian Keuangan dapat menjadi Anggota Pokja ULPD selain pegawai yang memiliki sertifikat keahlian pengadaan barang/jasa dan melalui proses seleksi penerimaan Anggota Pokja ULPD.

Dengan demikian, honorarium yang diterima Pokja ULPD sangat tidak wajar jika dibandingkan dengan tingkat resiko yang dihadapi, beban kerja, dan tingkat keahlian yang dimiliki oleh Anggota Pokja ULPD. Untuk itu, perlu dilakukan peninjauan kembali terkait dengan tingkat kewajaran nilai honorarium yang diterima oleh Pokja ULPD disesuaikan dengan tingkat resiko, tingkat keahlian, dan beban kerja pengadaan barang/jasa pemerintah.

\section{6) Proses Pemberian Penjelasan}

Tahapan pemberian penjelasan (aanwijzing) merupakan tahapan di mana para penyedia berkesempatan untuk mengajukan pertanyaan kepada Pokja ULPD terkait dengan paket pengadaan, syarat dan ketentuan yang tertuang dalam dokumen pemilihan. Berdasarkan ketentuan, Pokja ULPD diminta untuk segera menjawab setiap pertanyaan yang diajukan sampai dengan batas akhir pemberian penjelasan. Dengan demikian, Pokja ULPD tidak diperkenankan untuk mengumpulkan pertanyaan baru dijawab belakangan. Pokja ULPD harus segera menjawab ketika ada pertanyaan dari peserta tender tanpa harus menunggu pertanyaan dari peserta yang lain.

Penundaan menjawab pertanyaan akan membuat tujuan adanya tahapan pemberian penjelasan tidak tercapai. Tahapan pemberian penjelasan bertujuan untuk memperjelas ruang lingkup paket pengadaan serta syarat dan ketentuan yang 
tercantum dalam Dokumen Pemilihan, sehingga terdapat kesamaan pemahaman antara Pokja ULPD dan peserta, sekaligus untuk mendapatkan masukan kemungkinan adanya koreksi atas Dokumen Pemilihan. Jika Pokja ULPD tidak segera menjawab tetapi mengumpulkan pertanyaan untuk dijawab kemudian, maka menurut penulis akan terjadi beberapa hal, yaitu: a) tidak terjalin komunikasi yang baik antara Pokja ULPD dengan penyedia; b) ruang lingkup pekerjaan, syarat dan ketentuan tender menjadi bias karena tidak terjalin komunikasi yang baik; dan c) penyedia tidak berminat untuk mengajukan pertanyaan.

Untuk itu, Pokja ULPD perlu meluangkan waktu untuk memberikan perhatian pada saat proses pemberian penjelasan berlangsung. Agar dalam proses pemberian penjelasan terjadi komunikasi yang baik, maka Pokja ULPD terlebih dahulu memberikan salam pembuka dan menyampaikan syarat-syarat serta ketentuan dalam proses e-tendering. Hal ini dilakukan untuk menarik minat para penyedia yang mengikuti tender tersebut. Lingkup pekerjaan, syarat-syarat dan ketentuan yang bersifat khusus sesuai dengan bidang pengadaan dimaksud dapat disampaikan terlebih dahulu sebelum ada yang menyampaikan pertanyaan untuk membuat peserta tender aktif dalam proses tanya-jawab tersebut. Selain itu, PPK beserta staf pendukung atau tenaga ahli juga perlu meluangkan waktu pada saat proses pemberian penjelasan berlangsung. Hal ini dilakukan jikalau terdapat pertanyaan atau koreksi yang harus dijawab oleh PPK. Dengan demikian, tahapan pemberian penjelasan dapat menjadi wadah untuk berinteraksi bagi setiap pihak dalam proses e-tendering.

\section{KESIMPULAN}

Berdasarkan hasil penelitian, maka dapat disimpulkan sebagai berikut: 1) Tujuan pelaksanaan e-tendering pada dasarnya belum tercapai secara keseluruhan. Masih terdapat keterlambatan proses tender yang disebabkan oleh pengulangan proses tender dan maintenance jaringan sistem e-tendering. Selain itu, pelaksanaan reverse auction masih belum sesuai dengan ketentuan pengadaan barang/jasa pemerintah. 2) Efisiensi pelaksanaan e-tendering terdiri dari efisiensi biaya dan kegiatan. Efisiensi biaya berupa biaya alat tulis kantor, biaya perjalanan, dan biaya rapat, sedangkan efisiensi kegiatan berupa efisiensi waktu dan tempat. Selain itu, terdapat efisiensi outcome e-tendering dari perbandingan antara nilai HPS dengan nilai kontrak pekerjaan. 3) Kecukupan biaya dan hasil pelaksanaan e-tendering telah memadai. 
Terjadi kecukupan biaya karena proses tender dilakukan melalui sistem sehingga biaya yang ditimbulkan sangat minim. Kecukupan hasil e-tendering yaitu penyedia barang/jasa telah sesuai dengan persyaratan administrasi, teknis, harga, dan kualifikasi. 4) Perataan pelaksanaan $e$ tendering berupa distribusi kegiatan dan manfaat telah sesuai. Distribusi kegiatan telah sesuai dengan ketentuan, di mana proses e-tendering sebagian besar merupakan tanggung jawab Pokja ULPD untuk menilai penyedia barang/jasa, sedangkan PPK sebagai penerima hasil $e$ tendering. Setiap pihak dapat merasakan manfaat pelaksanaan e-tendering berupa kemudahaan pelaksanaan, mengurangi intervensi, minimalisasi pertemuan secara langsung, keterbukaan proses, mengurangi terjadinya diskriminasi, dan memudahkan pengawasan proses tender. 5) Kepuasan para pihak dalam pelaksanaan e-tendering yaitu berupa kemudahan akses sistem $e$ tendering, keterbukaan persaingan dan proses tender, serta pengurangan beban kerja. Catatan tertentu terkait dengan kepuasan para pihak adalah maintenance jaringan yang menganggu jadwal tender, kurangnya pemahaman atas reverse auction, kewajaran nilai honorarium Pokja ULPD, dan tahap pemberian penjelasan yang belum sesuai dengan ketentuan. 6) Tujuan kebijakan e-tendering dari sisi value for money sudah sesuai dan tepat karena telah memberikan perhatian atas besaran nilai uang yang dikeluarkan dan memberikan manfaat nyata untuk masyarakat dan ekonomi.

Penulis menemukan bahwa ada beberapa hal yang perlu dibenahi dalam melaksanakan e-tendering, yaitu: 1) Perlu menetapkan pegawai secara tetap untuk menjadi Anggota Pokja ULPD yang memiliki tugas pokok melaksanakan $e$ tendering dan segala sesuatu terkait dengan pengadaan barang/jasa pemerintah di lingkungan Kementerian Keuangan Provinsi Sulawesi Selatan. 2) Perlu dilakukan pelatihan atau penyegaran pemahaman pengadaan barang/jasa pemerintah secara regular/berkala sehingga dapat menghindari kesalahan-kesalahan Pokja ULPD dalam melaksanakan proses $e$ tendering. 3) Perlu melakukan bimbingan teknis secara berkala kepada para penyedia untuk mengembangkan pemahaman terkait dengan proses tender dan pengadaan barang/jasa secara keseluruhan. Hal ini dilakukan agar surat penawaran yang disampaikan penyedia lengkap dan memenuhi syarat serta dapat memahami aplikasi e-tendering secara baik mengingat sistem terus mengalami perkembangan dan tidak semua penyedia memahami proses etendering secara benar. 4) Pokja ULPD bersama PPK perlu membahas paket tender 
bersama-sama terkait dengan persyaratan dan ketentuan tender, jenis pekerjaan yang ditenderkan, jenis penyedia yang akan mengerjakan pekerjaan, jangka waktu pelaksanaan tender hingga tanda tangan kontrak, rencana jenis pembuktian kualifikasi, dan jenis kontrak yang akan digunakan. 5) Pelaksanaan paket tender yang dapat dilakukan reverse auction harus sesuai dengan kriteria pekerjaan yang terdapat pada Peraturan LKPP Nomor 9 Tahun 2018 dan perlu dilakukan penyesuaian jadwal pembuktian kualifikasi untuk tender yang dapat dilakukan reverse auction, sehingga identitas penyedia yang mengikuti pembuktian kualifikasi tetap rahasia sampai ditetapkan menjadi pemenang tender. 6) Maintenance jaringan sistem pengadaan perlu dilakukan di luar jam kerja agar tidak mengganggu jadwal $e$ tendering sehingga tidak mengakibatkan penundaan jadwal tertentu pada tahapan $e$ tendering. Maintenance jaringan dapat dilakukan pada hari Sabtu dan Minggu atau di atas jam kerja. Selain itu, pelaksanaan maintenance jaringan sebaiknya disampaikan terlebih dahulu kepada Anggota Pokja atau Ketua Pokja sehingga dapat dilakukan antisipasi terlebih dahulu. Pemberitahuan dapat dilakukan by system terhadap nomor Ketua dan Anggota ULPD yang terdaftar di sistem. 7) Honorarium Anggota Pokja ULPD perlu dilakukan peninjauan ulang mengingat pelaksanaan $e$ tendering merupakan pekerjaan keahlian, memiliki beban kerja yang tinggi, dan resiko hukum atas setiap keputusan yang diambil. 8) Anggota Pokja ULPD perlu meluangkan waktu pada tahapan pemberian penjelasan, mengaktifkan komunikasi dengan terlebih dahulu memberikan salam pembuka dan menyampaikan hal-hal yang dianggap khusus dalam proses tender tersebut dan setiap pertanyaan yang masuk dari peserta tender harus segera dijawab sehingga terjalin komunikasi yang baik.

\section{REFERENSI}

Aditya, Johan R. dan Oktaviana, Sonya. (2015). Analisis Perubahan Metode Pengadaan Dari Konvensional Ke EProcurement Terhadap Transparansi Proses Pengadaan Studi Kasus: Inspektorat Jenderal Kementerian Keuangan (Skripsi, UNIVERSITAS INDONESIA).

Bawono, Indro. (2011). Evaluasi Atas Penerapan Pengadaan Barang/Jasa Secara Elektronik (E-Procurement) di Lingkungan Kementerian Keuangan. (Tesis, UNIVERSITAS INDONESIA.)

Dunn, William N. (2000). Pengantar Analisis Kebijakan Publik. Gadjah Mada University Press.

Faisol, Imam Agus dkk. (2014). Pengaruh Penerapan E-Procurement Terhadap Pencegahan Fraud Di Sektor Publik. JAFFA, Vol.2 No. 2, Oktober. 
Karyasa, I N. R. dkk. (2014). Analisis Faktor-Faktor Yang Mempengaruhi Gagal Lelang Pengadaan Barang dan Jasa Pemerintah Secara Elektronik (E-Procurement) di Kabupaten Badung". Jurnal Spektran, Vol. 2 No. 1, Januari.

Miles, Matthew B. dan Huberman, A. Michael. (1992). Analisis Data Kualitatif (Diterjemahkan oleh Tjetjep Rohendi Rohidi). Universitas Indonesia Press.

Mustafa, Khalid. (2010). Berapa Honor Panitia Pengadaan? (www.khalidmustafa.info).

Nasution, Siti Patimah. (2012). Evaluasi Pengadaan Barang/Jasa Pemerintah Secara Elektronik (E-Procurement) Pada LPSE Kementerian Keuangan.
(Tesis, UNIVERSITAS INDONESIA).

Radit. (2017). Menatap Masa Depan Pengadaan di Langit Dhanapala (Warta Eproc, edisi XVII).

Sadiqa, Sarah. (2017). Bangun Sistem Informasi, Kembangkan Paradigma Baru Pengadaan (Majalah KREDIBEL, edisi 9 Sep-Des).

Simatupang, Togar M. dan Kartika, Fanny. (2013). Manajemen Pengadaan Publik. Jurnal Pengadaan, Vol. 3 No. 3, November.

Udoyono, Kodar. (2012). E-Procurement dalam Pengadaan Barang dan Jasa untuk Mewujudkan Akuntabilitas di Kota Yogyakarta. Jurnal Studi Pemerintahan, Vol. 3 No. 1, Februari. 